\title{
A função Judicante na Esfera Administrativa
} 35

\author{
Alberto Bonfim
}

A Constituição Federal de 1946 (arts. 65, 87 e 94 a 123) delimitou as atribuições de cada um dos três Podêres da República, de forma a não se confundirem as respectivas atribuições. As próprias denominações dos Podêres já indicam o que cada um deve fazer no quadro governamental: O Legislativo - fazer leis; o Executivo - fazê-las cumprir; e o Judiciário - interpretá-las em caso de controvérsia.

Até ai tudo bem. Mas a complexidade do mundo moderno em tudo impõe divisões e subdivisões. O Legislativo se compõe, no âmbito federal, de Câmara dos Deputados e Senado; no âmbito estadıal, de Āssembléia Legislativa; e no municipal, de Câmara de Vereadores.

O Executivo conta, hoje, em nosso país, com 11 Ministérios. E o Judiciário, além das várias instâncias que lhe emprestam uma seriação hierárquica, conta também com órgãos de justiça especializada. Assim, temos a Justiça Militar, a Justiça Eleitoral e a Justiça do Trabalho, com as suas várias instâncias, além de dois tribunais de competência menos ampla, quais sejam o de Contas e Marítimo Administrativo.

O Tribunal de Contas poderia, de certo modo, ser classificado como órgão de Justiça legislativa, dada a sua condição de auxiliar do poder legisferante. E o Tribunal Marítimo Administrativo, como o nome indica, exerce sua atividade no âmbito do Executivo, para julgar as questões ligadas à Marinha Mercante, supervisionada pelo Ministério da Marinha.

Como já existe um Código do Ar, não seria demais criar-se um Tribunal Aeronáutico. E isso possivelmente ocorrerá, mais cedo ou mais tarde, pois os juristas internacionais já começam a falar até num Direito Astronáutico, com a entrada do engenho humano na terceira dimensão espacial.

Feita, assim, esta breve indicação da amplitude a que se estendeu o poder judicante, cabe um exame mais detido do aspecto que mais de perto interessa ao título dêste artigo.

O Estatuto dos Funcionários (Lei $\mathrm{n}^{2}$ 1.711, de 28 de outubro de 1952) contém nada menos de 51 artigos, compreendendo 2 titulos com 9 capitulos, sôbre o regime disciplinar dos servidores públicos, inclusive o processo administrativo e sua revisão, dispositivos êsses que encerram preceitos proibitivos e sanções punitivas, análogos aos do Código Penal.

Os inquéritos administrativos, para apuração de delitos funcionais, se realizam nos vários setores da administração pública, depois do conhecimento 
da denúncia sob a forma de tomada de depoimentos, inclusive acareações, juntada de documentos, custódia de objetos que constituam prova material, e laudos periciais, tudo numa evidente semelhança com o processo penal.

$\mathrm{O}$ art. 200 do Estatuto chama de instância administrativa o âmbito em que são apreciados e decididos os feitos de natureza disciplinar. De fato, os relatórios opinativos das comissões de inquérito, quando aprovados pela autoridade designadora das comissões, constituem verdadeiros julgamentos de processo. E não é sem propósito que o Estatuto emprega as palavras : inquérito (art. 220), defesa (art. 222), julgamento (art. 225, § 1. ${ }^{\circ}$ ), recurso (art. 168), testemunhas (art. 236), penalidade (art. 238), direito de pleitear (art. 169), prescrição de pena (art. 213), tudo numa linguagem técnica, inquestionàvelmente judiciária.

Embora o $\S 4 .^{\circ}$ do art. 141 da Constituição Federal admita o pronunciamento do Poder Judiciário sôbre tôdas as lesões de direito individual. e, portanto, as reclamaçốes dos funcionários em grau de recurso possam ser, como vêm sendo, julgadas por aquêle outro Poder, não se pode deixar de convir que as fases do processo administrativo, a partir da entrega do relatório da comissão de inquérito, constituam verdadeiros julgados tıo sentido judicativo da palavra.

Não apenas no regime disciplinar sobressai o aspecto judicante da ação do Estado sôbre os seus servidores. Também nos casos de reclamação sôbre direitos e vantagens (promoção, aposentadoria, licença, vencimento, nomeação, etc.) a decisão administrativa não escapa ao teor dos veredictos judicatórios, incluindo mesmo os recursos para as autoridades superiores, os quais constituem verdadeiras apelações.

A chefia de um órgão especifico é como que uma primeira instância; a seguir vem o órgão central de pessoal do Ministério, como uma segunda instância; depois os gabinetes ministeriais, como uma terceira instância, com o pronunciamento do Titular da Pasta, e, finalmente, vêm os órgãos auxiliares da Presidência da República (Departamento Administrativo do Serviço Público, Secretaria da Presidência da República e Consultor Geral da República), que ao emitirem sua opinião para orientar o mais alto Magistrado da Nação, em grau de recurso, funcionam como quarta e última instância na esfera administrativa. Isso o que se constata na prática.

Verifica-se, assim, uma tramitação tìpicamente judiciária nos feitos administrativos com a subida dos autos para julgamento nos diversos degraus da escala hierárquica dos órgãos e autoridades do Poder Executivo.

No regime disciplinar dos servidores públicos consagra o Estatuto um título especial à acumulação de cargos. Para aplicação dos respectivos dispositivos (arts. 188 a 193) sentiu a administração a necessidade de um regulamento, que foi baixado pelo Decreto n..$^{\circ} 35.956$, de 2 de agôsto de 1954, criando também uma comissão para «emitir parecer sôbre os casos de acumulação» (art. 15). A comissão pode promover diligências que se tornarem necessárias $\left(\S 2 .^{\circ}\right)$ e das decisões da comissão, aprovadas pelo Diretor Geral do D.A.S.P., cabe recurso ao Exmo. Sr. Presidente da República (§ 4\%). 
É, pois, mais um currículo judicante na esfera administrativa o regime da acumulação de cargos, apenas com a sistemática invertida. Enquanto no Poder Judiciário a $10^{2}$ instância é normalmente constituída de juiz singular $e$ as instâncias superiores são colegiadas, a Comissão de Acumulação de Cargos tem na sua primeira instância um órgão de deliberação coletiva e nas duas superiores, autoridades singulares: mas isso absolutamente não the retira o caráter judicatório. É aplicação da lei às situações individuais, que se apresentam de tal forma dispares que raramente se encontram dois casos. idênìicos.

A prática ensina que deveria haver uma comissão permanentz de inquérito, pelo menos, em cada Ministério. Inúmeras as irregularidades que freqüentemente se cometem. Atualmente, ao que consta, há dois órgãos com êsse tipo de comissão: o Departamento dos Correios e Telégrafos e a Estrada de Ferro Central do Brasil. É compreensivel a continuidade dêsses órgã ıs coletivos naquelas repartições, que aliás controlam milhares de funcionários, o primeiro em todo o território nacional e a segunda numa extensa área abrangendo três importantes Estados.

As comissões de inquérito permanentes trazem, sôbre as eventuais, a vantagem da prática continuada, de modo a formar a sua especialização, donde o rendimento em qualidade e quantidade. As desvantagens das comissões ocasionais são a improvisação e o desestímulo no respectivo trabalho. Normalmente ninguém quer fazer parte de comissão de inquérito, atividade não remunerada, acarretadora de inimizades e, ainda, sujeita a viagens. É quase preciso obrigar os funcionários a integrarem as comissões. Convite raramente se aceita. Por isso a existência permanente de servidores com essas atribuições específicas eliminaria êsses inconvenientes, e poderia dar uniformidade à apuração de irregularidades, facilitando o trabalho da primeira instância de julgamento na esfera administrativa, ou sejam pelos. diretores de repartição, onde os delitos funcionais ocorrerem.

Outro aspecto da judicância a merecer análise neste artigo é a dualidade de julgamento pelo mesmo delito. O funcionário peculatário, por exemplo, responde a prccesso administrativo e a processo penal pelo mesmo delito (art. 226 do Estatuto). É claro, nessa hipótese, que, pela lesão aos cofres: públicos (art. 207, VIII), o funcionário, em virtude do inquérito administrativo, é passivel da pena de perda do cargo. E pela prática do peculato (art. 312 do Código Penal) está sujeito a prisão e a multa.

São, pois, sanções de natureza diversa : $\mathrm{Na}$ primeira, a pena expulsa-o do emprêgo; e na segunda, sofre restrição à liberdade e ao patrimônio. Em ambas está em jôgo o sentido patrimonial, mas na primeira predomina o sen tido moral e na segunda o aspecto físico.

Porém a dualidad ede julgamento traz o inconveniente da possibilidade de absolvição numa esfera e condenação em outra, como várias vêzes já tem acontecido. No tocante a direitos e vantagens tem já também ocorrido o mesmo : A Administração nega e o Judiciário concede. Muito melhor seria que houvesse uma só esfera judicante, quer para os delitos funcionais, quer para os direitos pleiteados, eliminando assim a disparidade de conseqüências do julgamentc: : o funcionário ou seria absolvido ou condenado; nunca ao mesmo tempo condenado e absolvido. 
Um código funcional, incluindo direitos e vantagens bem com os delitos administrativcs, imporia tôdas as sanções ou conseqüências cabiveis : o funcionário condenado, assim pela Justiça Administrativa, conforme o caso, poderia ser também prêso e multado (penalmente), além de perder o cargo (administrativamente) e pagar os prejuizos (civilmente).

$\mathrm{E}$ no concernente aos direitos e vantagens evitar-se-ia o que hoje acontece : ficarem os diretores, ministros e o próprio Presidente da República sujeitos a verem reformadas pelo Poder Judiciário suas decisões cienegatórias de direitos pleiteados.

No tocante aos direitos e vantagens e demais relações entre o funcionário e o Estado, o Estatuto já conta com uma copiosa jurisprudência, além de legislação paralela, inclusive regulamentativa, de modo a formar um todo jurídico que só pode ser bem interpretado e aplicado mediante critério judicante.

A Justiça Administrativa teria, assim, jurisdição especial, como têm a militar, a eleitoral e a trabalhista. As autoridades administrativas, assim, aliviadas dos encargos de julgar, que passariam a êsse fôro judicatório especial, teria mais tempo para dedicar-se aos misteres especificos de suas repartições ou órgãos.

Mas parece que uma reforma capaz de possibilitar o advento da Justiça Administrativa com foros judiciários dependeria de reforma da Constituição. E seria, salvo melhor juizo, uma reforma muito proveitosa. E até justa, pois atualmente há muitos funcionários em diversas repartições, incumbidos de elaborar expedientes que são verdadeiras sentenças, sem os direitos e as vantagens que a toga merecidamente proporciona aos que as vestem. 